\title{
The Addition of Trichoderma sp. in Various Types of Organic Liquid Fertilizer to Increase NPK Nutrient Uptake and Soybean Production in Ultisol
}

\author{
DOI: $10.18196 /$ pt.v10i1.9814 \\ Rapialdi, Jamilah*, Milda Ernita \\ Master of Agrotechnology Study Program, Faculty of Agriculture, Universitas Tamansiswa Padang \\ Jl. Tamansiswa No. 9 Padang 25138, Indonesia \\ *Corresponding author, email: jamilah@unitas-pdg.ac.id
}

\begin{abstract}
Indonesia imports up to $70 \%$ of its domestic soybean needs from abroad. Therefore, it is necessary to increase soybean yields in Indonesia, among others, by providing Liquid Organic Fertilizer (LOF). The purpose of this study was to determine the effects of LOF enriched with Trichoderma sp. on the yield of Mutiara-1 soybean in Ultisol. The experiment was conducted on dry land with a pH of 4.66 (acidic) in Kuranij Village, Kuranji District, Padang. The experiment was arranged in a factorial completely randomized design consisting of two factors, including the dose of Trichoderma sp. and the type of LOF. The doses of Trichoderma sp. inoculants were 0, 1, and $2 \mathrm{~kg}$ for every $20 \mathrm{~kg}$ of fermented LOF main ingredients. The main ingredients of LOF used in this experiment were Chromolaena odorata, Tithonia diversifolia, and Trichoderma sp. Meanwhile, the type of LOF tested was according to the composition of the main ingredients, consisting of no LOF, Crocober, and Tithocroco. The data obtained were analyzed using ANOVA and continued with the LSD test at a 5\% significance level. The results showed that the addition of $2 \mathrm{~kg}$ of Trichoderma sp. inoculants to Tithonia + C. odorata (Tithocroco) resulted in the highest dry seed production, reaching 3.17 tons ha-1 or an increase of 38.42\% compared to those without LOF.
\end{abstract}

Keywords: Chromolaena odorata, Liquid Organic Fertilizer, Soybean, Tithonia diversifolia, Trichoderma sp.

\section{ABSTRAK}

Indonesia mengimpor hingga 70\% kebutuhan kedelai domestiknya dari luar negeri. Oleh sebab itu perlu upaya meningkatkan hasil kedelai di Indonesia antara lain dengan pemberian Pupuk Organik Cair (POC). Tujuan penelitian adalah untuk mengetahui peranan dari POC yang diperkaya dengan Trichoderma sp terhadap hasil kedelai Mutiara-1 pada Ultisol.Percobaan telah dilakukan di lahan kering dengan pH 4,66 (masam) di Kelurahan Kuranji, Kecamatan Kuranji Kota Padang. Percobaan mengqunakan berbagai jenis bahan utama dijadikan POC antara lain; Chromolaena odorata, Tithonia diversifolia dan Trichoderma sp. Percobaan dirancang dengan rancangan acak lengkap faktorial dengan 2 faktor perlakuan, yaknidosis Trichoderma sp. dan jenis POC. Dosis inokulan Trichoderma sp., terdiri dari 0, 1 dan 2 kg untuk setiap 20 kg bahan utama POC yang difermentasikan. Jenis POC yang diuji didasarkan pada komposisi bahan utama terdiri dari tanpa POC, Crocober dan Tithocroco. Data yang diperoleh dianalisis menggunakan ANOVA pada taraf nyata 5\% dan dilanjutkan dengan uji LSD taraf nyata 5\%. Dari hasil percobaan maka dapat disimpulkan bahwa pemberian 2 kg inokulan Trichoderma sp pada POC Tithonia + C.odorata (Tithocroco) menghasilkan produksi biji kering tertinggi mencapai 3,17 ton ha-1 atau meningkat 38,42\% dibandingkan dengan yang tidak diberi POC.

Kata Kunci: Chromolaena odorata, Pupuk Organik Cair, Kedelai, Tithonia diversifolia, Trichoderma sp.

\section{INTRODUCTION}

Trichoderma sp. is a saprophytic fungus im- use of Trichoderma sp. has also been developed as portant in the plant nutrient cycle. This fungus a biological agent in increasing plant resistance is involved in the transaction of nutrients in to disease caused by soil-borne fungi and others nature. Trichoderma sp. is commonly used in mak- (de Oliveira et al., 2014; Chamzurni et al., 2011). ing organic compost, especially from rice straw. Trichoderma sp. is believed to be able to accelerate Fermentation of rice straw using Trichoderma sp. the decomposition of organic matter in nature so has a positive impact on increasing the nutrient that it can shorten the fermentation time, which content of compost and fertilizing the soil. The is quite long. Trichoderma is green in color with

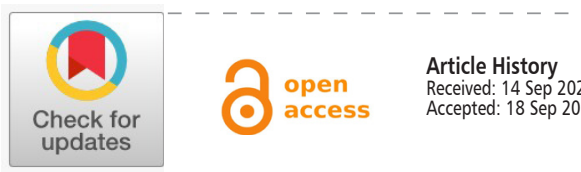


a slightly tart and sweet aroma. Usually, people breed it using rice or rice and bran media. The culture media must contain carbohydrates so that the fungus can live to meet the food from these carbohydrates.

The use of LOF using Trichoderma sp. has been reported by Putri\& Jamilah (2018).Rizal \& Susanti (2018) have also reported increased food crop yields using these fungi as decomposers. The manufacture of liquid organic fertilizer (LOF), which is used by spraying it over the entire surface of the plant evenly and periodically, has been reported by Jamilah et al.(2015). The popular liquid organic fertilizer comes from shrubs and agricultural waste. Besides cleaning the environment, it also plays a role in inserting these materials into the food chain in nature. The use of Chromolaena odorata as LOF (Crocober plus and Unitas Super) has been successful in various crops of rice, corn, soybeans, vegetables, and fruits (Jamilah \& Permana, 2015; Jamilah, Fadhila, \& Mulyani, 2017). However, aside from C. odorata, many other shrubs can be used as the main ingredients for LOF, including Tithonia diversifolia. This plant has been reported to increase the yield of upland rice by $13.33 \%$ (Jamilah \& Juniarti, 2015). T. diversifolia has a high content of $\mathrm{N}$ and $\mathrm{K}$, so it can be used as material for making fertilizers. The advantages of these two types of shrubs are that they are resistant to pruning and quickly recover their growth, and they are easy to produce large clumps.

Tithonia as the main ingredient of LOF, which increased $13.33 \%$ of paddy field rice, has been reported by Jamilah, Maradona, Zahanis, \& Ernita (2014). The combination of C. odorata and Tithonia is suitable for manufacturing LOF equipped with Trichoderma sp. There is no information on the effectiveness of all these ingredients on food crops. Therefore, the manufacture of LOF is necessary. In addition to reducing the purchase of artificial fertilizers, LOF also overcomes the shortage of nutrients in plants. Liquid organic fertilizer contains macro and micronutrients, so it is very suitable as a complementary fertilizer with expensive artificial fertilizers.

Soybean yields in Sumatra are significantly low, with an average of only 1.25 tons ha ${ }^{-1}$ compared to production in Java, which can reach 1.6 tons ha ${ }^{1}$ (BPS, 2021). Soybean production in the United States is 34 bushels per acre or equivalent to 2.13 tons ha $^{-1}$ (Brumm, 2003), making them an exporter of soybeans, including to Indonesia. The problem of low soybean yields in Indonesia is caused by, among others, low soil fertility (especially Ultisols), limited availability of artificial fertilizers, and many pests and diseases. It should be noted that the demand for soybeans in Indonesia is very high. Indonesia imports $70 \%$ of its domestic soybean needs (Satria, 2015). The use of superior varieties such as Mutiara-1 (BATAN, 1998)is very beneficial because of the large grain size and high yield per hectare $\left(3.5\right.$ tons $\left.\mathrm{ha}^{-1}\right)$. Therefore, applying LOF to soybean cultivation in West Sumatra is necessary. The purpose of this study was to determine the effects of LOF enriched with Trichoderma sp. on the levels of N, P, K and yield of Mutiara-1 soybean in Ultisol.

\section{MATERIALS AND METHODS}

The experiment was conducted on dry land with a pH of 4.66 (acidic) in Kuranji Village, Kuranji District, Padang.This experiment used various main ingredients to manufacture liquid organic fertilizer (LOC), including C. odorata, T. diversifolia, manure, coconut fiber, local microorganisms, and Trichoderma sp. The experiment was arranged in a factorial, completely randomized design, consisting of two factors. The first factor was the doses of Trichoderma sp. inoculants, which were 0,1 , and $2 \mathrm{~kg}$ for every $20 \mathrm{~kg}$ of the fermented main 
ingredients of the LOF. The second factor was the type of LOF based on the composition of the main ingredients, consisting of no LOF, Crocober (C. odorata + Coconut Coir + Manure + MOL), and Tithocroco (T. diversifolia + C. odorata + Coconut husk + Manure + MOL). The data obtained were analyzed using ANOVA with a significance level of $5 \%$. The data showing significant differences between treatments were tested using LSD with a significance level of 5\% (Steel \& Torrie, 1980). The observations were made on plant $\mathrm{N}, \mathrm{P}$, and $\mathrm{K}$ levels, the weight of 100 seeds, number of pods per plant, pithy pods, and dry seed weight per plot and per hectare. $\mathrm{P}$ analysis was performed using the wet ashing method with $\mathrm{H} 2 \mathrm{SO} 4$ and $\mathrm{H} 2 \mathrm{O} 2$, then the extract was read on a spectronic device, and $\mathrm{K}$ was determined using the AAS tool (Eviati \& Sulaeman, 2009).

LOF was prepared based on the same ratio except for local microorganisms (MOL). The compositions of the ingredients were Crocober (C. odorata + Coconut Coir + Manure + MOL) and Tithocroco (T. diversifolia + C. odorata + Coconut husk + Manure + MOL) (Jamilah \& Novita, 2016) (Jamilah\& Ben, 2018). All the determined main ingredients were finely chopped, stirred, and fermented for two weeks in a humid atmosphere by covering them tightly. Local microorganisms were made by crushing papaya fruit waste into old coconut water fermented using sugar for two weeks. The fermented main ingredient of LOF was added with $1 \mathrm{~kg}$ or $2 \mathrm{~kg}$ of Trichoderma sp. in $20 \mathrm{~kg}$ of mixed ingredients as the forerunner to LOF. Groundwater was then added, with a ratio to LOF of 1:1. The fertilizer was fermented again for two weeks in a tightly closed container. LOF was harvested after the aroma disappeared, which was indicated by the darkened color.

Soybean seeds were planted two seeds in each planting hole with a spacing of $20 \times 25 \mathrm{~cm}$ on a plot measuring $2 \times 2 \mathrm{~m}$. The soil was pulverized, and two weeks before planting, liming using dolomite equal to 1 x Aldd was carried out. The basic fertilizers given were $50 \mathrm{~kg}$ Urea, $100 \mathrm{~kg}$ SP36, and $100 \mathrm{~kg} \mathrm{KCl}$ per hectare, which were applied ten days after planting. The LOF was applied on soybean plants by taking every $50 \mathrm{ml}$ of LOF solution dissolved in 1 liter of water and sprayed evenly and smoothly over the plant shoots. LOF application was carried out every other week and stopped when the plants started filling pods. From the results of this activity, LOF was applied to plants only three times.

Pest and weed were difficult to control because the intensity of the rain was too high. Plants (two clumps/plots) were destroyed 43 days after planting to determine plant $\mathrm{N}, \mathrm{P}$, and $\mathrm{K}$ levels and shoot dry weight. The remaining plants were kept until harvest. Crops are ready to harvest when the pods become yellowish and hard.

\section{RESULTS AND DISCUSSION}

The NPK levels were determined at the end of the vegetative growth phase (Figure 1). The NPK levels in soybean plants during the lower primordia phase were generally more influenced by the type of LOF than by Trichoderma sp. or the combination of both. The impact of Trichoderma sp. was not significantly able to increase the $\mathrm{P}$ and $\mathrm{K}$ levels, but there was an effect on the $\mathrm{N}$ levels of plants.

The N, P, and K levels were higher in the plants treated with Crocober. Meanwhile, the lowest level of $\mathrm{N}$ was observed in the plants without LOF application. The impact of LOF on the $\mathrm{P}$ and $\mathrm{K}$ levels was not significantly different. Plants absorb N, P, $\mathrm{K}$, and other elements. However, the N, P, and K elements are classified as macro elements needed by plants. Nutrient levels of these plants will then affect the growth and yield of soybean plants. Compared to the $\mathrm{P}$ and $\mathrm{K}$ content of soybeans cultivated 


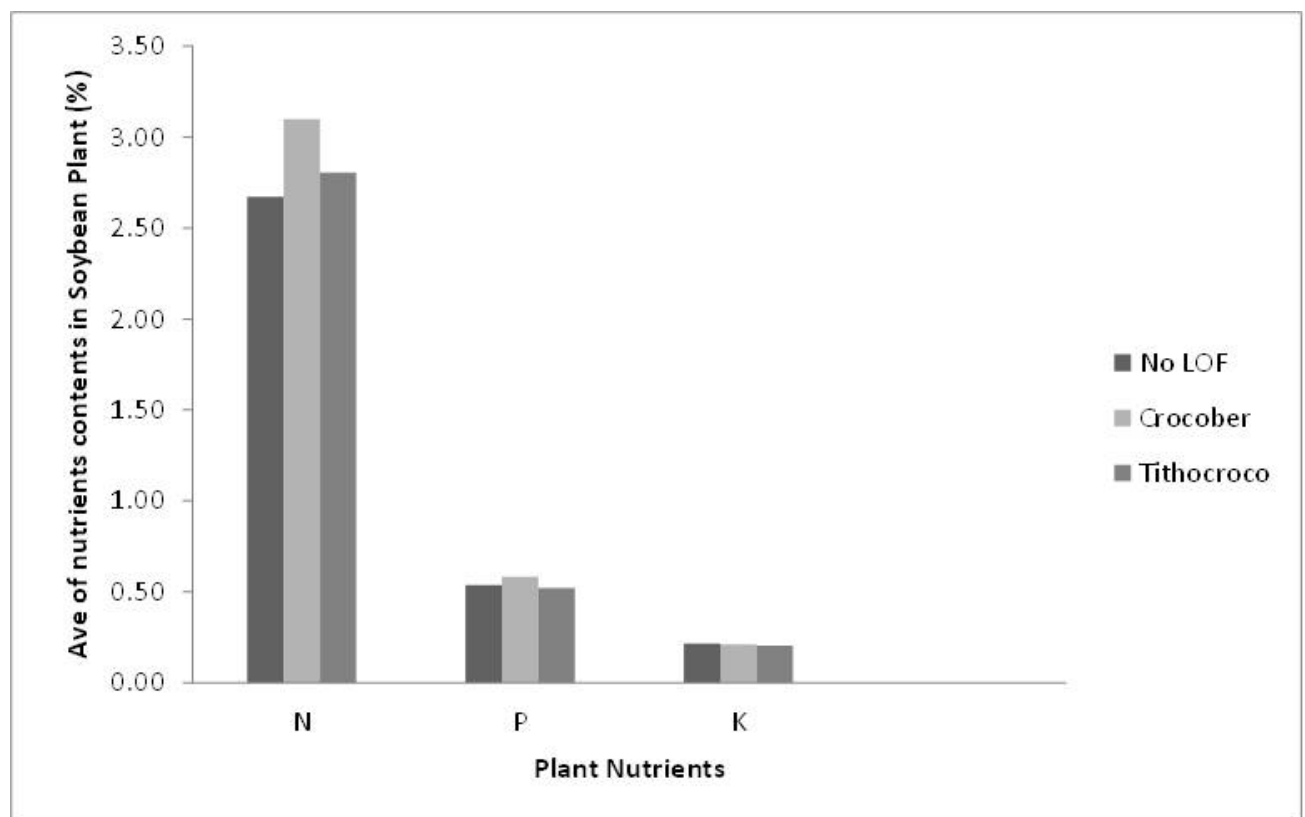

Figure 1. NPK levels in soybean plants at 43 days after planting

in Lampung, the P level in soybeans was higher in tion of organic matter contained in the LOF so West Sumatra, but the mean level of $\mathrm{K}(<0.5 \%)$ that it is easy to mineralize, releasing ions such was much lower than in Lampung $(0.6-0.8 \%)\left(\mathrm{Wi}-\right.$ as $\mathrm{NO}_{3}^{-1}, \mathrm{~K}^{+}$, and $\mathrm{HPO}_{4}^{2}$. Plants can immediately janarko \& Taufiq, 2004). Plants with sufficient N, absorb these ions. Nutrients maximally absorbed $\mathrm{P}$, and $\mathrm{K}$ nutrients will produce optimal metabolic by plants during the growth phase will increase activity. $\mathrm{N}$ is important in increasing the amount of the number of soybean pods. Even if given $2 \mathrm{~kg}$ leaf chlorophyll so that the $\mathrm{N}$ assimilation activity of Trichoderma sp. inoculants, Tithocroco could is optimal, producing high organic matter.

produce the highest number of pods compared to

There was an interaction effect of LOF and other treatments.

Trichoderma sp. on the plant $\mathrm{N}$ level and shoot dry weight at 43 days after planting (Table 3). In general, the addition of $1 \mathrm{~kg}$ of Trichoderma sp. inoculants for every $20 \mathrm{~kg}$ of LOF main ingredients was able to increase $1 \%$ of plant $\mathrm{N}$ levels. However, if the dose of Trichoderma sp. inoculant increased again, plant $\mathrm{N}$ levels did not increase. The application of Crocober was able to increase plant $\mathrm{N}$ level compared to Tithocroco.

The addition of Trichoderma sp. significantly increases the effectiveness of LOF in improving plant growth. This is because Trichoderma sp. can produce hydrolysis enzymes, glucanase, proteases, and chitinase (Gómez, Chet, \& Herrera-Estrella, 1997). The enzyme will accelerate the decomposi-
Table 1 shows the interaction effect of Trichoderma sp. and LOF on $\mathrm{N}$ level and dry weight of plant crown per clump. $\mathrm{N}$ level was influenced more by the interaction of LOF and Trichoderma sp., as explained above. Crocober was superior in producing the highest $\mathrm{N}$ levels in plants, either with or without the addition of Trichoderma sp. The high nutrient content in the plant material will be translocated to the storage section or seeds during the seed filling phase. Photosynthate produced by the green part of the plant will be translocated into storage media, either in seeds, stem, roots, or leaves as sinks (Oosterhuis, 2009; Setiawan, Rosadi, \& Kadir, 2014; Tanah \& Penelitian, 2005; Tan, 2013). Plants treated with the addition of $2 \mathrm{~kg}$ of Tricho- 
Table 1. The results of the interaction test of Trichoderma sp. and LOF on $\mathrm{N}$ levels and shoot dry weight of soybean plants per clump

\begin{tabular}{|c|c|c|c|c|c|c|}
\hline \multirow{3}{*}{ Type of LOF } & \multicolumn{6}{|c|}{ Application of Trichoderma sp. (kg/20 kg of the LOF's main ingredient) inoculants } \\
\hline & \multicolumn{3}{|c|}{$\mathrm{N}$ level $(\%)$} & \multicolumn{3}{|c|}{ Shoot dry weight per clump (g) } \\
\hline & 0 & 1 & 2 & 0 & 1 & 2 \\
\hline Without LOF & $1.96 \mathrm{BC}$ & $3.22 \mathrm{Aa}$ & $2.84 \mathrm{Ab}$ & $13.00 \mathrm{Ab}$ & $18.22 \mathrm{Aa}$ & $14.56 \mathrm{Bb}$ \\
\hline Crocober & $3.33 \mathrm{Aa}$ & 3.07 Aab & $2.91 \mathrm{Ab}$ & 14.14 Aa & 14.36 Ba & $17.15 \mathrm{Aa}$ \\
\hline Tithocroco & $2.98 \mathrm{Aa}$ & $3.12 \mathrm{Aa}$ & $2.32 \mathrm{Bb}$ & $12.15 \mathrm{Ab}$ & 17.25 ABa & $19.51 \mathrm{Aa}$ \\
\hline
\end{tabular}

Remarks: Means followed by the same letters in the same column are not significantly different according to LSD test at $5 \%$.

Table 2. Effects of the doses of Trichoderma sp.for every $20 \mathrm{~kg}$ of LOF main ingredients on the number of pods

\begin{tabular}{cc}
\hline Doses of Trichoderma sp.(kg/20 kg LOF main ingredients) & Number of pods per clump \\
\hline 0 & $32.81 \mathrm{~B}$ \\
1 & $33.82 \mathrm{~B}$ \\
2 & $37.48 \mathrm{~A}$ \\
\hline
\end{tabular}

Remarks: Means followed by the same letters in the same column are not significantly different according to LSD test at 5\%.

Table 3. Effects of LOF on the number of filled pods and weight of 100 seeds

\begin{tabular}{ccc}
\hline Type of LOF & Number of filled pods (\%) & Weight of 100 seeds (g) \\
\hline Without LOF & $83.14 \mathrm{~A}$ & $22.31 \mathrm{~A}$ \\
Crocober & $82.69 \mathrm{AB}$ & $21.64 \mathrm{~A}$ \\
Tithocroco & $79.19 \mathrm{~B}$ & $20.88 \mathrm{~A}$ \\
\hline
\end{tabular}

Remarks: Means followed by the same letters in the same column are not significantly different according to LSD test at $5 \%$.

Table 4. Effects of the addition of Trichoderma sp. to LOF on the weight of dry seeds at a moisture content of $14 \%$

\begin{tabular}{ccccccc}
\hline & \multicolumn{4}{c}{ Application of Trichoderma sp. (kg/20 kg of the LOF's main ingredient) inoculants } \\
\cline { 2 - 6 } Type of LOF & \multicolumn{3}{c}{$\begin{array}{c}\text { Weight of dry seeds at a moisture } \\
\text { content of 14\% (g plot-1) }\end{array}$} & $\begin{array}{c}\text { Weight of dry seeds at a moisture content of 14\% } \\
\text { (ton ha-1) }\end{array}$ \\
\cline { 2 - 7 } & 0 & 1 & 2 & 0 & 1 & 2 \\
\hline Without LOF & $919.88 \mathrm{Aab}$ & $912.92 \mathrm{Ab}$ & $1082.31 \mathrm{Ba}$ & 2.29 & 2.28 & 2.70 \\
Crocober & $967.38 \mathrm{Aa}$ & $1009.84 \mathrm{Aa}$ & $946.13 \mathrm{Ba}$ & 2.42 & 2.52 & 2.36 \\
Tithocroco & $925.03 \mathrm{Ab}$ & $912.94 \mathrm{Ab}$ & $1268.88 \mathrm{Aa}$ & 2.31 & 2.28 & 3.17 \\
\hline
\end{tabular}

Remarks: Means followed by the same letters in the same column are not significantly different according to LSD test at $5 \%$.

derma sp. for every $20 \mathrm{~kg}$ of LOF main ingredients produced a higher number of pods (Table 2). The higher doses of Trichoderma given will increase the number of pods per clump. There was no significant effect of LOF on the number of soybean pods per clump, but a significant effect on rice pods was observed. This proves that LOF is a nutrient needed by plants for filling their pods.

The number of filled pods and the weight of 100 seeds were not affected by the application of LOF and Trichoderma sp. (Table 3). The weight still not optimal because the weight of 100 seeds of 100 seeds was not affected by fertilization but was more determined by plant genetics.Based on BATAN (1998) and Riniarsi (2015), the weight of 100 seeds of soybean cv. Mutiara-1 reached 23.2 $\mathrm{g}$, much larger than that of other varieties, which were only around $8.36 \mathrm{~g}$ for the Tanggamus and Sibayak varieties(Wijanarko \& Taufiq, 2004). The weight of 100 seeds in this study did not match the description of the Mutiara-1 variety, which is likely because the nutrients received by soybean plants are 
has the potential to be increased again.

There was an interaction effect of LOF and inoculants on the weight of dry seeds at a moisture content of $14 \%$. The highest dry seed production was observed in the plants treated with the addition of $2 \mathrm{~kg}$ of Trichoderma sp. inoculants in every $20 \mathrm{~kg}$ of Tithocroco (Table 4). All types of LOC without Trichoderma sp. resulted in the lowest dry seed production. This result shows that adding Trichoderma sp. to the LOF is important. Its impact has been proven on the uptake of $\mathrm{N}, \mathrm{P}$, and $\mathrm{K}$ nutrients, which subsequently affect the vegetative growth and ultimately increase the production of dry seeds.

In general, the addition of Trichoderma sp. to all LOF treatments gave high seed yields. The addition of $2 \mathrm{~kg}$ of Trichoderma/ $20 \mathrm{~kg}$ of the main ingredient of Tithocroco was able to produce the highest seed weight, reaching 3.17 tons $\mathrm{ha}^{-1}$. Plants only given Trichoderma sp. produced the lowest dry seed weight. However, the combination treatment of $2 \mathrm{~kg}$ of Trichoderma sp. inoculants with $20 \mathrm{~kg}$ of Tithocroco produced the highest dry seed weight, reaching 3.17 tons $\mathrm{ha}^{-1}$, which was increased by $38.42 \%$ compared to plants without LOF and Trichoderma sp.

\section{CONCLUSION}

From the experimental results, it can be concluded that the addition of $2 \mathrm{~kg}$ of Trichoderma sp. inoculants in every $20 \mathrm{~kg}$ of Tithocroco resulted in the highest dry seed production, reaching 3.17 tons $\mathrm{ha}^{-1}$, increased by $38.42 \%$ compared to those not given with LOF.

\section{ACKNOWLEDGEMENT}

The authors would like to thank the Ministry of Education and culture for funding the research under contract no. 092/LL.10/PG/2020, March 11, 2020. Gratitudes are also expressed to the Rector of the University of Tamansiswa Padang for supporting this research as well as the head of LPPM and the Dean of the Faculty of Agriculture Universitas Padang for facilitating this research.

\section{REFERENCES}

BATAN. (1998). Kedelai Varietas Unggul Baru Hasil Pemuliaan Mutasi Radiasi. (P. D. I. Nuklir, Ed.). Jakarta: Batan.

BPS. 2021. Analisis produktivitas jagung dan kedelai di Indonesia 2020 (Hasil Survei Ubinan). Penerbit BPS-RI.

Brumm, T. J. (2003). Quality of the 2003 Soybean Crop in the United States. Agricultural and Biosystems Engineering, 1(2), 2-18.

Chamzurni, T., Sriwati, R., \& Selian, D. (2011). efektivitas dosis dan waktu aplikasiTrichoderma virens TERHADAP serangan Sclerotium rolfsiipada kedelai.Floratek, 6(1), 62-73.

de Oliveira, J. A. M., Nurdin, M., \& Suskandini, R. D. (2014). penggunaanTrichoderma sp. sebagai agensia pengendalian terhadapPyricularia oryzae Cav. penyebab blas pada padi. J. Agrotek

Tan. K.H. (2013). Humo-Nanotube Membrane Relation With Biopolymers. In Journal of Chemical Information and Modeling (Vol. 53, pp. 1689-1699). Department of Crops and Soil Science The University of Georgia, Athens, GA, USA PREFACE. https://doi. org/10.1017/CB09781107415324.004

Eviati, \& Sulaeman. (2009). Analisis Kimia Tanah, Tanaman, Air dan Pupuk. (B. H. . Prasetiyono \& D. Santoso, Eds.) (2nd ed.). Bogor: Balai Penelitian Tanah, Bogor.

Gómez, I., Chet, I., \& Herrera-Estrella, A. (1997). Genetic diversity and vegetative compatibility among Trichoderma harzianum isolates. Molecular and General Genetics, 256(2), 127-135. https://doi.org/10.1007/s004380050554

Jamilah\& Ben Kurniawan, Z. (2018). Pengaruh pupuk organik cair UNITAS SUPER asal Chromolaena odorata terhadap pertumbuhan dan hasil padi hitam ( Oryza sativa L.). Jurnal Agroteknologi, $8(2), 15-20$

Jamilah, Ediwirman, \& Ernita, M. (2015). the Effect of Fermented Liquid Organic Fer- Tilizer and Potassium for Nutrient Uptake and Yield of Rice At Tropical Upland. J. Environ.Res.Develop., 9(4), 1-6.

Jamilah, Fadhila, R., \& Mulyani, S. (2017). Farm analysis of rice crop trimmed periodically in the tropical wet. In International Conerence on Social, Humanities and Government Science (Vol. 1, p. 631). https://doi.org/10.1016/S0969-4765(04)00066-9 Jamilah, \& Juniarti. (2015). Potensi Tanaman Padi Dipangkas Secara Periodikuntuk Pakan Ternak Pada Metoda Budidaya Integrasi Padi Ternak Menunjang Kedaulatan Pangan Dan Daging. :aporan Penelitian Fakultas Pertanian Univ. Tamansiswa, Padang (Vol. 53). Padang.

Jamilah, Maradona, C., Zahanis, \& Ernita., M. (2014). Penetapan konsentrasi dan nterval pemberian POC asal sabut kelapa dan thitonia untuk meningkatkan hasil padi ladang (Oriza sativa L.). In Pros.Sem.Nas. Politani Payakumbuh, Sumatera Barat (Vol. 1, pp. 53-62). Payakumbuh, Sumatera Barat: Politeknik Pertaian Negeri Payakumbuh.

Jamilah, \& Novita, E. (2016). Pengaruh Pupuk Organik Cair Crocober Terhadap Tanaman Bawang Merah (Allium ascalonicum L.). 
Jurnal Ipteks Terapan, 2(2), 67-73.

Jamilah, \& Permana, D. (2015). Aplikasi pupuk organik cair asal C.odorata + sabut kelapa dan asam humat untuk tanaman Stroberi (Fragaria ananassaa). Prosiding Seminar Nasional Ketahanan Pangan Dan Pertanian Berkelanjutan Politeknik Pertanian Negeri Payakumbuh, 31-36.

Oosterhuis, D. (2009). Foliar fertilization: mechanisms and magnitude of nutrient uptake. Proceedings of the Fluid Forum, 15-17.

Putri, L. A., Jamilah, Widodo H. (2018). Pengaruh pupuk organik cair dan Trichoderma sp terhadap pertumbuhan dan hasil melon ( Cucumis melo ). Jurnal Bibiet, ISSN 2502-0951, 3(1), 17-24.

Riniarsi, D. (2015). Kedelai. Jakarta: Pusat Data dan Sistem Informasi Pertanain Kementerian Pertanian.

Rizal, S., \& Susanti, T. D. (2018). Peranan Jamur Trichoderma sp yang Diberikan terhadap Pertumbuhan Tanaman Kedelai ( Glycine max L .). Sainmatika, 15(1), 23-29. https://doi.org/10.31851/ sainmatika.v15i1.1759

Satria. (2015). Produksi Kedelai Nasional Masih Rendah. Jogya karta. Setiawan, W., Rosadi, B., \& Kadir, M. Z. (2014). ( Glycine max [ L ] Merr .) Pada Beberapa Fraksi Penipisan Air Tanah Tersedia Response Of Growth And Yield Of Three Variety Of Soybean ( Glycine max [ L ] Merr .) on some available soil water depletions, Jurnal Teknik pertanian Lampung3(3), 245-252.

Steel, R. G. D., \& Torrie, J. H. (1980). Principles and Procedures of Statistics: A Biometrical Approach. Biometrics, 37(4), 859. https://doi.org/10.2307/2530180

Tanah, B. P., \& Penelitian, B. (2005). Analisis Kimia Tanah , Tanaman , Air , Dan Pupuk. Balai Penelitian Tanah Badan Penelitian dan Pengembangan Pertanian Departemen Pertanian.

Wijanarko, A., \& Taufiq, A. (2004). Pengelolaan Kesuburan Lahan Kering Masam Untuk Tanaman Kedelai. Bulletin Palawija, 50(7), 39-50. 